\title{
Exploring Expressions of Marital Love Prototype among Married Urban Malays
}

\author{
S. M. Hoesni ${ }^{1}$, I. H. M. Hashim ${ }^{2}$ \& W. M. H. Sarah ${ }^{1}$ \\ ${ }^{1}$ School of Psychology and Human Development, Faculty of Social Sciences and Humanities, Universiti \\ Kebangsaan Malaysia, Bangi, Malaysia \\ ${ }^{2}$ School of Social Sciences and Humanities, Universiti Sains Malaysia, Penang, Malaysia \\ Correspondence: S. M. Hoesni, School of Psychology and Human Development, Faculty of Social Sciences and \\ Humanities, Universiti Kebangsaan Malaysia, 43600 UKM Bangi, Selangor, Malaysia. Tel: 60-3-8921-3628. \\ E-mail: smh@ukm.my
}

Received: August 7, 2012 Accepted: January 2, 2013 Online Published: January 28, 2013

doi:10.5539/ass.v9n2p245 URL: http://dx.doi.org/10.5539/ass.v9n2p245

\begin{abstract}
The aim of this study is to explore the prototype for expressions of marital love among urban Malays. This study applies the process for developing prototypes of love which was adapted by Fehr (1988). Questionnaire consisting of questions relating to personal background, relationship background and list of expressions of marital love were presented to 600 working married urban Malays. Data were analyzed using Principal Component Analysis (PCA) and found that the list for prototype expressions of marital love were fit using the three component definition as suggested by Sternberg (1986), specifically, intimacy to intimate-sharing expressions, commitment to commitment-faith expressions and passion to romantic-physical expressions. Results showed that expressions for marital love which involve intimate-sharing expressions (e.g. listening to spouse's emotional outpourings, encouraging spouse, solving problems with spouse) were most desirable compared to romantic-physical expressions which were less desirable (e.g. holding spouse's waist, giving spouse a massage, caressing spouse). Findings suggest future studies on love within marriage should consider cultural aspects and application of implicit theory as suggested by Fehr (1988).
\end{abstract}

Keywords: expressions of love, marital love, prototype, marriage, urban Malays

\section{Introduction}

Since early civilizations, Greek philosophers such as Socrates and Plato have debated on the subject of love. Love was defined by Plato as an emotion that exists in a hierarchical form, whereas Socrates argued that love is a combination of many elements (Levy, 1979). Love has also been well-documented in the Malay culture. Daillie (2002) and Salleh (2007) investigated old manuscripts including poems and found that although Malay culture was less expressive about passionate love, as bounded by its social norms and values, love was expressed freely in the form of poetry. In this context, poems were found to provide socially acceptable ways of expressing feelings and the emotions of love.

While people from the restricted Malay culture as well as respected Greek philosophers recognized the importance of love, psychologists have only recently focused on the subject. Furthermore, the development of scientific knowledge concerning love has been slow and incomplete. It took a while for love to be recognized as a scientific field of research in the area of psychology. Harlow (1959) expressed his concern when psychologists at that time 'failed' to recognize the importance of psychological studies on love. Elkins and Smith (1979) analyzed psychology literature from the early 1940s until the1970s. They found that there was a 20-year gap in the publications as well as in the effort to examine love scientifically until the early 1970s. In addition, a study by Curtin (1973) found that love was not discussed in 23 annual reviews of psychology during the 1940s and up until the 1960s.

One possible explanation for the lack of scientific research in psychology focusing on love at that time was because love might be seen as intangible and immeasurable. Scientific psychology holds a principle that human mind and behaviour can be examined only through observable data. Behaviourism, for example, is a school of thought in psychology that holds firmly to this principle. Behaviourism also dominated the field of psychology 
particularly social psychology from the early nineteenth century until twentieth century. This may explain why limited studies have focused on love before 1970s.

However, recently, the focus of psychology has returned to inspecting aspects of the mind. This is especially true in the field of positive psychology. Positive psychology is an area of psychology that uses scientific and applied methods to explore an individual's strengths and encourages the positive functioning of an individual (Snyder \& Lopez, 2007). It recognizes the importance of love in understanding the complexity of human beings (Compton, 2001; Snyder \& Lopez, 2007). As such, more and more studies have focused on love.

Despite the encouraging recent development on the psychological studies on love, these studies tend to overly focus on specific participants and aspects of love (Dion \& Dion, 1996; Fehr, 2006; Woodward, 2003). To illustrate, most of single or dating participants involved in the studies on love were college and undergraduate students who were in their early adulthood and in the early stages of close relationships. Thus, the reports that contributed to the field of the psychology of love mostly reflect their experience as individuals who were in the early stages of close relationships such as dating and falling in love (Hendrick \& Hendrick, 1986; Yela, 1999). There has been a lack of research on the more 'mature' kind of love such as marital love or love among older couples.

Researchers such as Fehr (1988), Yela (1999) and Woodward (2003) also expressed concern over the inappropriateness of applying general concept of love within a specific stage of love relationship. For instance, Woodward found a specific definition for studying love within long committed relationships named as mature passionate love. Woodward discovered that passionate love within long-term relationships has deeper meaning compared to the passionate love in early love relationship. It includes affection, differentiation, sexual openness, trust and transcendence.

Other researchers found companionate love (Grote \& Friez, 1998) and commitment love (Montgomery \& Sorell, 1997) as important dimensions of love within marriage. The need for further research on studying love within marriage has been supported by many researchers (Bergner, 2000; Bonds-Raacke et al., 2001; Ismail, 2004; Woodward, 2003). These studies indicated the importance of differentiating various dimensions of love that may be associated with different stages of a relationship including marital love.

Another issue relating to the academic and scientific knowledge of love in psychology is that most love theories were developed in the West. Most of the current studies on love have been conducted within the context of European and American cultures. However, certain research findings have shown that culture plays an important role in determining the meanings of love. For example, a study carried out by Gonzaga, Turner and Keltner (2006) discovered that Asian participants valued love less in a committed relationship compared to Caucasian participants. These findings further supported by Qadir, De Silva, Prince and Khan (2005) that found fulfilling the needs and expectations of family and society were more important to the participants from non-western culture compared to personal needs (such as love). Another study by Grote and Frieze (1998) also found there were different ways between Caucasians and non-Caucasians perceive and express love within marriage, nonetheless, achieving similar marital satisfaction.

The above results indicated that even though love is viewed as important in many different cultures, they may be expressed and experienced differently. Indeed some slight cultural differences on how love is experienced have continued to be discovered among Hispanics (Leon, Parra, Cheng \& Flores, 1995; Parra, Brown, Huynh, Stubbs, \& Amerson, 1998; Parra, Brown, Phung, Thao, Stubbs, Leon, \& Mejia, 2001), Chinese (Cho \& Cross, 1995), Portuguese (Neto, 1995), Serbians (Todosijević, 2009) and Malays (Hoesni, 2001, 2003).

How people view and express love may also be influenced by certain aspects such as individual and relationship factors. Sex (Dion \& Dion, 1993; Fehr \& Broughton, 2001), age (Neto, 2001; Yancey \& Eastman, 1995) and level of education (Hoelter, Axinn, \& Ghimire, 2004) play a role in determining how love is viewed, expressed and experienced within marriage. Relationship factors such as time together with the partner (Grote \& Friez, 1998), total number of children (Montgomery \& Sorell, 1997), may also influence marital satisfaction and the well-being of the person.

From the discussion, it can be concluded that it is important for psychologists to focus on the subject of love. However, studies on love should go beyond the early dating stages and young college couples and Western samples as are the case of previous studies. As an attempt to contribute to this research gap, this study focuses on expressions of marital love among urban Malays. Thus, the implicit psychological theories of love such as the prototype theory of love (Fehr, 1988) offer an alternative explanation for love. This approach to studying love acknowledges how individuals give personal meaning to love rather than depending solely on the existing dimensions of love that have been developed by explicit theorists on love. Implicit perspectives also allow 
researchers to carry out a deeper investigation into love because they allow elements which are familiar to the person in the study. As an example, Fehr and Russell (1991) found that certain kinds of love may be more prototypical than other kinds, for example, friendship love is more prototypical compared to love of work. This finding indicated that laypersons do not view love as researchers assume. Laypersons only relate to the love concept from their own experiences of love.

The prototypical theory of love (Fehr, 1988) also enables researchers to explore love in a specific context such as love experienced in a specific culture or ethnic group. This is because implicit perspectives of love allow laypersons to play an active role by reporting own familiar concepts and experiences of love in a study as influenced by their own culture. As a result, new elements which are culture or ethnic-specific can appear in the study when investigating love. This helps to contribute towards a more comprehensive knowledge of love within psychology.

In addition, an advantage of implicit perspectives of love enable researcher to explore specific love processes within a relationship. For instance, many studies have found the importance of relating love to a specific context such as asking participants to describe an episode of love (Shaver \& Hazan, 1988), love as experienced in a marital relationship (Fitness \& Fletcher, 1993), asking respondents how they know that they are in love (Lamm \& Weismann, 1997) and how love relates to behaviour indicators of love (Buss, 1988). This is important to the contribution of the knowledge relating to love since researchers found that laypersons view love differently in different situations. The importance of exploring love relating to life experiences has also been strongly suggested by Fehr (2006) as follows, "In future research, it will be important to further explore the idea that people organize their knowledge of love into different levels of abstraction and to discover which body of knowledge is most likely to be accessed when making relationship-relevant decisions" (Fehr 2006, p.234). Hence, it is vital for researchers to first understand the concept of love as perceived by the group of people that they are studying before proceeding to any further investigation on love. This is to ensure that the concept of love is parallel between the researcher and the group being studied and to avoid any misconceptions on the psychological knowledge of love. This was supported by Fehr and Russell (1991) that future researchers should analyze the concept of love prior investigating the subject of love in depth. Thus, applying the implicit perspectives in this study, the researcher is able to explore love within specific context such as the types of love within committed relationships, group specific and to explore specific love processes within a relationship.

\section{Method}

\subsection{Background of Participants and Sampling}

This study consisted of 600 married urban Malays working in governmental organizations in Federal Territory. Sample frame was gained using a list consisting of 261 governmental organizations and agencies. Only those situated within Federal Territory were chosen. Sample size was determined with the help of online survey calculator as suggested by Dyer (2006). A combination of simple random and multistage cluster random sampling was carried out. Simple random sampling was executed using the "tombola method" (Dyer, 2006, p.?) and 20 organizations were chosen. Next, the multistage cluster sampling was executed at the organization level. The researcher contacted the human resource department of each organization. Upon agreement, questionnaires were distributed by the representative.

\subsection{Measurements}

Questionnaires in this study consisted questions relating to personal background, relationship background of participants and Expressions of Marital Love Scale (EML).

\subsection{Demographic Information}

The demographic section consisted of questions relating to personal background of participants. This included personal information such as sex, age, religion, education level, personal monthly income and household income.

\subsection{Relationship Information}

This section contained questions regarding participants' relationship with spouse. This included the total number of years participants have been married, total number of children, age of eldest child, age of youngest child and length of time getting to know spouse before deciding to get married and discrepancy between participants' expressions of marital love and participants' perception on their spouses' expressions of marital love.

\subsection{Expressions of Marital Love Scale (EML)}

The EML consisted of expressions of marital love. The scale was developed from free listing of expressions of love in four situations (in public, in the presence of in laws and relatives, in the presence of children and in 
private) as described in a study by Hoesni et al. (2011). Hoesni et al. has adapted the keyword extraction process as recommended by Braun and Clarke (2006). The open-ended answers with similar keywords or phrases were coded, thus, resulting in different themes and a total of 63 items. Responses were measured using 5-Likert scale, $1=$ 'strongly disagree' and $5=$ 'strongly agree'. All 63 items from the EML had been tested on their reliability. Overall the EML items were found to exceed the minimum requirement of alpha Cronbach as suggested by Anastasi (1988). Reliability scores using Cronbach alpha for the EML were reported at 0.97 .

\subsection{Procedures}

First, the researcher visited the identified organizations with the letter of consent after an appointment had been made. A set of 30 questionnaires together with individual envelopes were passed to the representative of each organization. Next, the researcher explained the procedures involved in answering the questionnaires to the representatives. A time frame was set to enable the representatives to disseminate the questionnaires to participants. After the time frame had been met, the researcher collected the questionnaires from the respected representatives. However, the whole procedure was repeated if the total of expected return of questionnaires did not meet the targeted sample size. The procedure stopped when sample size reached 600 participants.

\subsection{Analysis}

Statistical Package for Social Sciences version 19 for Windows (SPSS 19) was applied to manage and assists researcher in analyzing the collected data. Data in this study was analyzed using descriptive and inferential statistics. Descriptive statistics were carried out to analyze the personal and relationship background of participants using minimum, maximum, percentages, mean and standard deviation scores.

All 63 items from the EML were subjected to principal component analysis (PCA) using SPSS 19. This was to summarize the items into three components of love - intimacy, passion and commitment as proposed in Triangular Love Theory (Sternberg, 1986). The PCA process was necessary for a new developed measurement used in a study (Hair, Black, Babin, Anderson \& Tatham, 2006; Loewenthal, 2001; Tabachnick \& Fidell, 2001). Before proceeding with PCA, the suitability of factor analysis was assessed through several procedures. The suitability of data for PCA was inspected by using correlation matrix and Kaiser-Meyer-Oklin (Kaiser, 1970, 1974) along with the Bartlett's Test of Sphericity (Bartlett, 1954). If the data was found to be suitable Varimax and Oblimin Rotation were used to investigate the structure within the EML using Triangular Love Theory (Sternberg, 1986) as a guideline.

\section{Results \& Discussion}

\subsection{Background of Participants}

This study consisted of $68.6 \%$ female and $30.8 \%$ male. The mean age for participants were 35.52 years with standard deviation was 8.49 years. The age ranged from 20 years old until 61 years old. All participants were Malay Muslim. The three highest level of education among participants were participants with a first degree (Bachelors) (33.8 \%). This was then followed by Malaysian Certificate of Education (SPM) $(24.8 \%)$ and Diploma (22.2 \%). The mean for participants' monthly income was RM3053.00 with $S D=$ RM2039.40. Monthly income ranged from lowest RM450.00 until highest RM15000.00. Those participants' household income ranged from RM600.00 to RM35000.00 with a mean of RM6370.00 and $S D=4490.50$.

\subsection{Relationship Background of Participants}

The mean length of marriage was 9.7 years with $S D=8.30$ years. The range length of marriage for participants was from 0.96 months to 36 years. Most participants had two children (21.7\%). This was followed by three children (19.7\%), one child (18.8\%) and childless (16.5\%). Participants' age of eldest child ranged from 0.08 years to 33 years. The mean of eldest child age was 9.84 years with $S D=7.90$ and their age ranged from 0.08 years to 24 years. The mean for youngest child age was 5.00 years with $S D=5.39$ years. The mean length for participants to know partner before wedding ranged from one month to 328 months. The mean was 34.64 years with $S D=32.26$ months. Majority of participants chose their partner personally. This was then followed by family arrangement (6.7\%) and a combination of personal, family and friends (4.3\%).

\subsection{Expressions of Marital Love (EML) among Married Urban Malays}

EML was assessed using the EML scale developed by the researcher. This scale consisted of items that were related to how participants express their marital love. The items that participants express marital love most in descending order was "respecting spouse" $(M=4.57, S D=0.64)$, "contacting spouse when apart (such as via text messages, emails, telephone calls)" $(M=4.55, S D=0.78)$, "upholding moral character for spouse" ( $M=$ $4.52, S D=0.66)$, "assisting spouse" $(M=4.51, S D=0.67)$, "appreciating spouse" $(M=4.50, S D=0.66)$, 
"worthy of spouse's trust" $(M=4.48, S D=0.69)$, "becoming a devout husband/wife for spouse" $(M=4.45, S D$ $=0.72)$ and "truthful with spouse" $(M=4.44, S D=7.60)$.

Conversely, the items that participants least agreed on expressions of marital love in ascending order was "bathing with spouse" $(M=3.12, S D=1.25)$, "holding spouse's waist" $(M=3.38, S D=1.14)$, "giving spouse a massage" $(M=3.97, S D=0.97)$, "looking deeply into spouse's eyes" $(M=3.81, S D=1.00)$, "evoking memories of love from the past" $(M=3.97, S D=1.09)$, "caressing spouse" $(M=4.03, S D=0.95)$, "leading spouse's hands" $(M=4.05, S D=1.04)$, "uttering loving words to spouse" $(M=4.05, S D=0.99)$, "buying gifts for spouse" $(M=4.10, S D=.95)$ and "courteous with spouse" $(M=4.14, S D=0.77)$.

\subsection{Exploring Components Expressions of Marital Love (EML) among Married Urban Malays}

The items were subjected to principal component analysis (PCA). All 63 items from EML were subjected using Principal Component Analysis (PCA) using SPSS 19. Before proceeding to PCA, the suitability for factor analysis was assessed through several procedures. First, this was carried out by inspecting the correlation matrix for the items and results showing the presence of many correlation values of 0.3 and above. Then, Kaiser-Meyer-Oklin value was inspected at value of 0.97 which exceeded the recommended value at 0.6 (Kaiser, 1970, 1974). At the same time, the Bartlett's Test of Sphericity (Bartlett, 1954) reached statistical significance which supports the factorability of the correlation matrix.

PCA showed the existence of nine components with eigenvalues exceeding 1 in a respective order of explaining $42.34 \%, 5.37 \%, 2.99 \%, 2.52 \%, 2.38 \%, 2.15 \%, 2.03 \%, 1.91 \%, 1.82 \%$ and $1.58 \%$. An inspection of the scree plot shows a clear break after the third component. By using Catell's (1966) scree test, it was decided to retain three components for further inspection.

In helping to interpret the expressions of marital love components, Varimax rotation was executed. The rotated solution showed the presence of simple structure (Thurstone, 1947). Both of the components showed a number of strong loadings and all variables loading substantially on one component. The three components solution explained a total of 50.69 of the variance with component 1 contributing $24.84 \%$, component 2 contributing $15.81 \%$ and $10.05 \%$.

Consequently, the researcher decided to include all 63 EML items according to three components of love. Results in Table 1 show that all items from the EML fell into three components which were intimate-sharing expressions (38 items), romantic-physical expressions (17 items) and commitment-faith expressions (8 items) (Please refer to table A1 and A2 for the overall variable loadings). All items under three components were scrutinized with the guidance of Triangular Love Theory (Sternberg, 1986). As a result, the three components resembled general descriptions as described by Triangular Love Theory (Sternberg, 1986) which were intimacy, passion and commitment.

Table 1. Examples of EML items

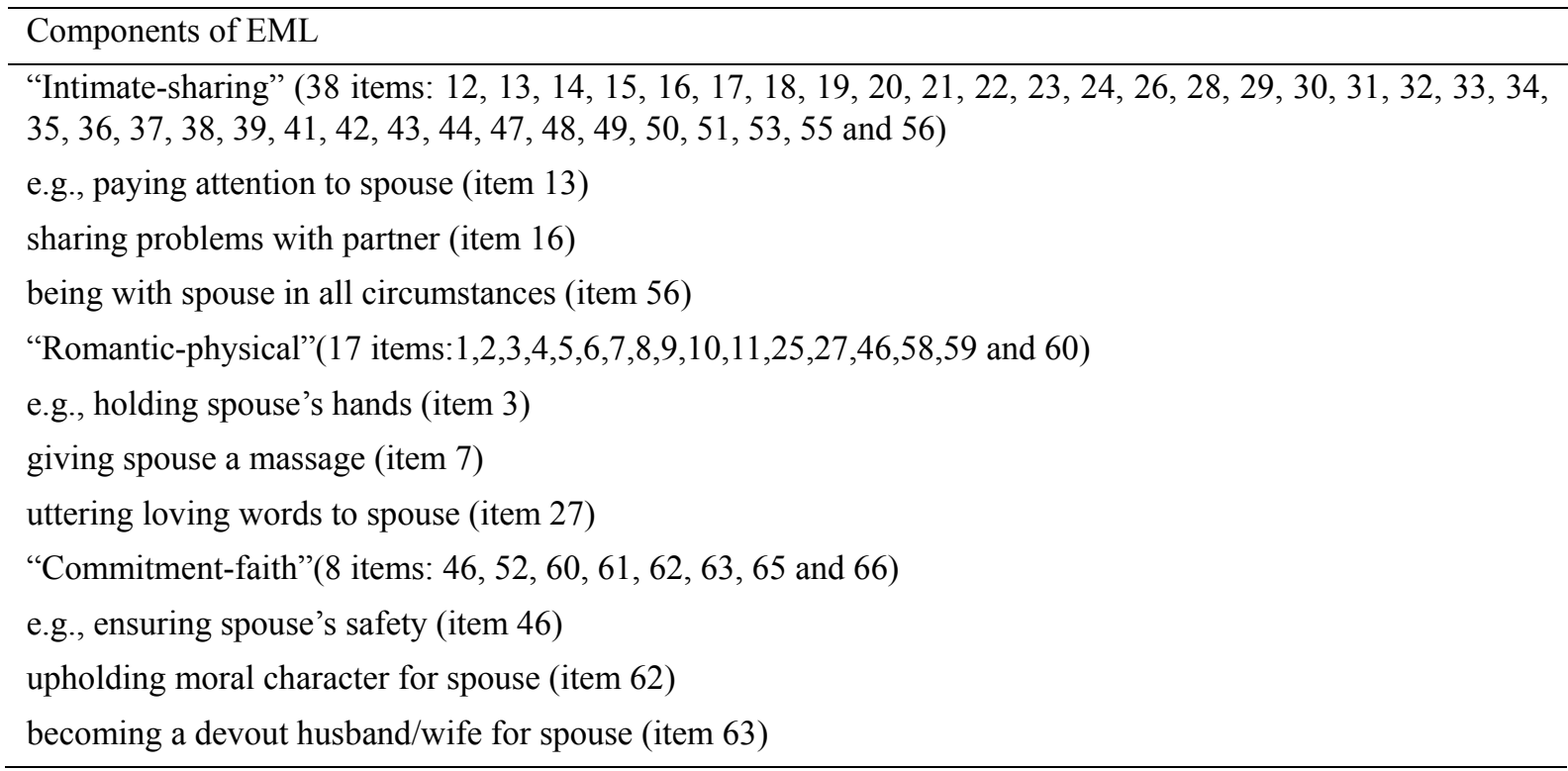

As a result of the items that fell under the three components, the researcher named and defined the three components as intimate-sharing expressions, romantic- physical expressions and commitment-faith expressions. 
The definitions for each component were developed according to the summary of items under each component. According to Tabachnick and Fidell (2001), each component was best named using the first five strongest factor loadings that fell under each component. In addition, the name for each component should also not use similar term as found under each component. Therefore, the researcher named and defined the three components as shown in Table 2.

Table 2. Definition of EML dimensions

\begin{tabular}{ll}
\hline EML dimensions & Definition of EML dimensions \\
\hline $\begin{array}{l}\text { Intimate - sharing } \\
\text { expressions }\end{array}$ & $\begin{array}{l}\text { This type of EML is characterized by unique and intimate expressions to the married } \\
\text { couple. It includes emotional aspect of being close to the spouse. In addition, the type } \\
\text { of communication that exists in this type of expression includes having an ethical way } \\
\text { of communicating which helps to maintain a harmonious marital relationship. Besides } \\
\text { a healthy communication, this type of expression also includes taking care and } \\
\text { maintaining spouse's well-being as a husband or a wife (e.g., paying attention to } \\
\text { spouse, sharing problems with partner and being with spouse in all circumstances) }\end{array}$ \\
$\begin{array}{l}\text { This kind of EML involves close physical contact that leads or does not lead to sexual } \\
\text { intercourse (e.g., holding spouse's hands, giving spouse a massage and uttering loving } \\
\text { expressions }\end{array}$ & $\begin{array}{l}\text { words to spouse) } \\
\text { Commitment - Faith } \\
\text { expressions }\end{array}$ \\
$\begin{array}{l}\text { Commitment-faith related EML were inspired from the Islamic way of life of being an } \\
\text { ideal husband or wife. This type of expressions is characterized by expressions that } \\
\text { was meant to maintain an existing a marital knot under the teachings of Islam (e.g. } \\
\text { ensuring spouse's safety, upholding moral character for spouse and becoming a devout } \\
\text { husband/wife for spouse) }\end{array}$
\end{tabular}

The researcher decided to apply EML for further analyses. The researcher's decision was supported from descriptions made by Loewenthal (2001) and Hair, Black, Babin, Anderson and Tatham (2006) for all the items to be summarized under the three components as suggested by PCA.

Results found that there were three main aspects of EML as reported by participants. All the three components were based on Triangular Love Theory (1986). EML consisted of intimate-sharing expressions, romantic-physical expressions and commitment-faith expressions. Among the three components of EML, important elements came mostly from intimate-sharing expressions and several from the commitment aspect. This included contacting spouse when apart, assisting spouse, respecting spouse, appreciating spouse, being truthful to spouse and worthy of spouse's trust from the intimate-sharing expressions. Furthermore, the few important elements from commitment-faith expressions were upholding moral character for spouse and becoming a devout spouse. On the other hand, the least important expressions came from the romantic-physical aspect of marital love. This includes bathing with spouse, holding spouse's waist, giving spouse a massage, looking deeply into spouse's eyes, evoking memories of love from the past, caressing spouse, leading spouse's hands and uttering loving words to spouse.

At the same time, results suggested that although romantic-physical component of EML were reported as least important, it has significant negative relationships towards other demographic (sex, age of participants, monthly income and household income of participants for demographic factors) and relationship background factors (total years of marriage, total number of children, age of youngest and eldest child of participants). For example, romantic-physical EML tended to decrease as participants' age increased, income increased, longer period that they remained married, the age of children increased and total number of children increased. Male and female participants also differed in how they express marital love especially from intimate-sharing expressions and romantic-physical EML.

In conclusion, findings suggested that a more specific definition should be applied when studying marital love among individuals coming from specific contexts such as relationship status and culture/ ethnic groups. Findings also indicated that the most important expressions of marital love came from intimacy-sharing expressions and the least came from romantic-physical expressions.

\section{References}

Anastasi, A. (1988). Psychological testing: Sixth Edition. New York: Macmillan.

Bartlett, M. S. (1954). A note on the multiplying factors for various chi square approximations. Journal of the 
Royal Statistical Society, 16(Series B), 296-298.

Bergner, R. (2000). Love and barriers to love: An analysis for psychotherapists and others. American Journal of Psychotherapy, 54, 1-17.

Bonds-Raacke, J. M., Bearden, E. S., Carriere, N. J., Anderson, E. M., \& Nicks, S. D. (2001). Engaging distortions: Are we idealizing marriage? The Journal of Psychology, 135(2), 179-184. http://dx.doi.org/10.1080/00223980109603689

Braun and Clarke. (2006). Using thematic analysis in psychology. Qualitative research in Psychology, 3, 77-101. http://dx.doi.org/10.1191/1478088706qp063oa

Buss, D. M. (1988). Love acts: The evolutionary biology of love. In R. Sternberg, \& M. Barnes (Eds.), The Psychology of Love (pp. 100-118). New Haven: Yale University Press.

Catell, R.B. (1966). The scree test for number of factors. Multivariate Behavioral Research, 1, 245-276. http://dx.doi.org/10.1207/s15327906mbr0102_10

Cho, W., \& Cross, S. E. (1995). Taiwanese Association with self esteem and relationship quality. Genetic, Social \& General Psychology Monographs, 121, 283-310.

Compton, W. (2005). Love and Well Being in Introduction to Positive psychology. Singapore: Thomson Learning.

Curtin, M. E. (1973). Symposium on love. New York: Behavioral Publications. In Murthy, K., \& Rotzien, A. (Eds.), Educational \& Psychological Measurement (pp. 108-121). Second - order structure underlying the Hendrick-Hendrick Love Attitudes Scale.

Daillie, F. R. (2002). Alam pantun Melayu (Studies on the Malay Pantun). Kuala Lumpur, Dewan Bahasa Pustaka.

Dion, K. K., \& Dion, K. L. (1996). Cultural perspectives on romantic love. Personal Relationships, 3(1), 5-17. Dion, K. K., \& Dion, K. L. (1993). Sex and ethno cultural comparisons in styles of love. Psychology of Women Quarterly, 17, 463-473. http://dx.doi.org/10.1111/j.1471-6402.1993.tb00656.x

Dyer, C. (2006). Research in psychology: A practical guide to methods and statistics. Victoria: Blackwell Publishing.

Elkins, G. R., \& Smith, D. (1979). Meaning and measurement of love: A review of humanistic and behavioural approaches. Humanist Educator, 18(1), 7-14. http://dx.doi.org/10.1002/j.2164-6163.1979.tb00185.x

Fehr, B. (1988). Prototype analysis of the concepts of love and commitment. Journal of Personality and Social Psychology, 4, 557-579. http://dx.doi.org/10.1037/0022-3514.55.4.557

Fehr, B. (2006). A prototype approach to studying love. In Sternberg, R. J., \& Weis, K. (2006). The New Psychology of love, 225-246.

Fehr, B., \& Broughton, R. (2001). Sex and personality differences in conceptions of love: An interpersonal theory analysis. Personal Relationships, 8, 115-136. http://dx.doi.org/10.1111/j.1475-6811.2001.tb00031.x

Fehr, B., \& Russell, J. A. (1991). The concept of love viewed from a prototype perspective. Journal of Personality and Social Psychology, 60, 425-438. http://dx.doi.org/10.1037/0022-3514.60.3.425

Fitness, J., \& Fletcher, G. J. O. (1993). Love, hate, anger and jealousy in close relationships: A prototype and cognitive appraisal analysis. Journal of Personality and Social Psychology, 65, 942-958. http://dx.doi.org/10.1037/0022-3514.65.5.942

Gonzaga, G. C., Turner, R. A., \& Keltner, D. (2006). Romantic love and sexual desire in close relationships. Emotion, 6(2), 163-179. http://dx.doi.org/10.1037/1528-3542.6.2.163

Grote, N. K., \& Frieze, I. H. (1998). "Remembrance of things past": Perceptions of marital love from its beginnings to the present. Journal of Social \& Personal Relationships, 15(1), 91-108. http://dx.doi.org/10.1177/0265407598151006

Hair, J. F., Black, B. B., Anderson, R., \& Tatham, R. (2006). Multivariate Data Analysis (6th ed.). Upper Saddle River, NJ: Prentice Hall.

Harlow, H. F. (1959). Love in infant monkeys. Scientific American, 200, 68-86. http://dx.doi.org/10.1038/scientificamerican0659-68

Hendrick, C., \& Hendrick, S. (1986). A theory and method of love. Journal of Personality and Social Psychology, 
50, 392-402. http://dx.doi.org/10.1037/0022-3514.50.2.392

Hoesni, S. M. (2001). Profil Caragaya Cinta Remaja Akhir Perempuan Melayu. Unpublished master's thesis, Universiti Kebangsaan Malaysia.

Hoesni, S. M., Hashim, I. H. M., Sheau, T. C., Mohamad, S. M., Kamaruzaman Jusoff, Subhi, N., Sarnon, N., Nen, S., \& Lukman, Z. M. (2011). Subjective meanings and expressions of marital love among soon to be married urban Malays. World Applied Sciences Journal, 12, 25-28.

Hoesni, S.M. (2003). Profil cara gaya cinta perempuan Melayu bujang. Jurnal Psikologi dan Pembangunan Manusia, 19, 125-140.

Ismail, R. (2004). Hubungan Kesulitan Ekonomi Dengan Kefungsian Keluarga, Hubungan Perkahwinan Dan Tingkah Laku Keibubapaan Etnik Rungus, Iranun Dan Melayu. Kota Kinabalu: Universiti Malaysia Sabah.

Kaiser, H. (1970). A second generation Little Jiffy. Psychometrika, 35, 401-415. http://dx.doi.org/10.1007/BF02291817

Kaiser, H. (1974). An index of factorial simplicity. Psychometrika, 39, 31-36. http://dx.doi.org/10.1007/BF02291575

Lamm, H., \& Wiesman, U. (1997). Subjective attributes of attraction: How people characterize their liking, their love and their being in love. Personal Relationships, 4, 271-284. http://dx.doi.org/10.1111/j.1475-6811.1997.tb00145.x

Leon, J. L., Parra, F., Cheng, T., \& Flores, R. E. (1995). Love-styles among Latino community college students in Los Angeles. Psychological Reports, 77, 527-530. http://dx.doi.org/10.2466/pr0.1995.77.2.527

Levy, M. B., \& Davis, K. E. (1988). Lovestyle and attachment styles compared their relations to each other and to various relationship characteristics. Journal of Social and Personal Relationships, 5, 439-471. http://dx.doi.org/10.1177/0265407588054004

Loewenthal, K. M. (2001). An introduction to psychological tests and scales (2nd ed.). Philadelphia: Psychology Press Ltd.

Montgomery, M. J., \& Sorell, G. T. (1997). Differences in love attitudes across family life stages. Family Relations, 46(1), 55-61. http://dx.doi.org/10.2307/585607

Neto, F. (1995). Love styles of the three generations of women. Marriage and Family Review, 33(4), 19-31. http://dx.doi.org/10.1300/J002v33n04_03

Neto, F. (2001). Love styles of three generations of women. Marriage and family Review, 33(1), 19-31. http://dx.doi.org/10.1300/J002v33n04_03

Parra, F., Brown, W. C., Huynh, P. D., Stubbs, E. C., \& Amerson, K. C. (1998). Love styles among Guatemalans in a local village. Psychological Reports, 83, 1199-1202.

Parra, F., Brown, W. C., Phung, D. H., Thao, T. T. P. L., Stubbs, E. C., Leon, J. J., \& Mejia, A. (2001). Sex Differences in Love-Styles Among Adult Latino Spanish Speaking Parents Whose Children Have Been Sexually Abused by the Father. Journal of Child Sexual Abuse, 9(2), 107-113. http://dx.doi.org/10.1300/J070v09n02_07

Qadir, F., De Silva, P., Prime, M., \& Khan, M. (2005). Marital satisfaction in Pakistan: A pilot investigation, 20, 2, 195-209.

Salleh, M. (2007). Cinta sepanjang hayat. Prosiding seminar pantun Melayu: Semalam, Hari ini dan esok. 6-7 ${ }^{\text {th }}$ Disember 2007, Institut Alam dan Tamadun Melayu, Universiti Kebangsaan Malaysia. Edited by Supyan Hussin and Ding Choo Ming.

Shaver, P. R., \& Hazan, C. (1988). A biased overview of the study of love. Journal of Social and Personal Relationships, 5, 473-501. http://dx.doi.org/10.1177/0265407588054005

Snyder, C. R., Lopez, S. J., \& Pedrotti, J. T. (2010). Positive Psychology: The scientific and practical explorations of human strengths (2nd ed.). London: Sage Publications.

Sternberg, R. J. (1986). A triangular theory of love. Psychological Review, 93, 119-135. http://dx.doi.org/10.1037/0033-295X.93.2.119

Tabachnick, B. G., \& Fidell, L. S. (2007). Using Multivariate Statistics (5th ed.). Boston: Allyn and Bacon.

Todosijević, B. (2009). An Examination and Revision of the Love Attitude Scale in Serbia. Interpersona, 3(1), 
$55-74$

Woodward, A. (2003). Mature passionate love-Not only possible but heavenly! Australian Journal of Psychology, Supplement, 55, 233.

Yancey, G. B., \& Eastman, R. L. (1995). Comparison of undergraduates with older adults on love styles and life satisfaction. Psychological Reports, 76, 1211-1218. http://dx.doi.org/10.2466/pr0.1995.76.3c.1211

Yela, C. (1999). Temporal course of the basic components of love throughout relationships. Psychology in Spain, 2(1), 76-84.

Yela, C. (2006). The evaluation of love: Simplified version of the scales for Yela's Tetrangular Model Based on Sternberg's Model. European Journal of Psychological Assessment, 22(1), 21-27. http://dx.doi.org/10.1027/1015-5759.22.1.21

\section{Appendixes}

Table A1. Pattern/structure for coefficients: Varimax rotation of EML 2 for 63 items

\begin{tabular}{|c|c|c|c|}
\hline Item (no.) & $\mathrm{C} 1$ & $\mathrm{C} 2$ & $\mathrm{C} 3$ \\
\hline Being worthy of spouse's trust & .743 & .165 & .223 \\
\hline Discussing with spouse & .737 & .341 & .106 \\
\hline Being sincere towards spouse & .735 & .189 & .268 \\
\hline Sharing stories with spouse & .732 & .276 & .075 \\
\hline Respecting spouse & .728 & .317 & .169 \\
\hline Cooperating with spouse & .722 & .293 & .211 \\
\hline Appreciating spouse & .721 & .307 & .221 \\
\hline Undestanding spouse & .707 & .296 & .226 \\
\hline Solving problems with spouse & .692 & .278 & .085 \\
\hline Sharing problems with spouse & .691 & .266 & .110 \\
\hline Assisting spouse & .685 & .340 & .173 \\
\hline Communicating well with spouse & .669 & .366 & .170 \\
\hline Exchanging views with spouse & .666 & .400 & .099 \\
\hline Being truthful with spouse & .665 & .109 & .267 \\
\hline Paying attention to spouse & .656 & .371 & .205 \\
\hline Being considerate of spouse's feelings & .646 & .367 & .212 \\
\hline Concerned with the entire well-being of spouse & .641 & .249 & .284 \\
\hline Listening to spouses's emotional outpourings & .640 & .319 & .196 \\
\hline Making spouse happy & .639 & .394 & .236 \\
\hline Giving words of encouragement to spouse & .616 & .380 & .165 \\
\hline Encouraging spouse & .596 & .441 & .140 \\
\hline Contacting spouse when apart (such as via text messages, emails, telephone calls) & .587 & .270 & .274 \\
\hline Being with spouse in all circumstances & .584 & .166 & .394 \\
\hline Being faithful to spouse & .583 & .237 & .238 \\
\hline Ensuring and maintaining cleanliness of the thome for spouse & .562 & .193 & .203 \\
\hline $\begin{array}{l}\text { Performing household duties with spouse (paying bills, doing the shopping, helping out } \\
\text { with the children's homework, taking care of the children) }\end{array}$ & .549 & .208 & .274 \\
\hline Speaking gently with spouse & .541 & .388 & .203 \\
\hline Accepting spouse for who he/she is & .539 & .124 & .329 \\
\hline
\end{tabular}


Dining with spouse

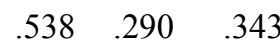

Obtaining useful information for spouse

$\begin{array}{lll}.531 & .239 \quad .378\end{array}$

Trusting spouse

$.529 \quad .210 \quad .89$

Being courteous to spouse

$.517 \quad .394 \quad .246$

Joking with spouse

$.507 \quad .487 \quad .198$

Carrying out recreational activities with spouse (such as watching television, going out)

$.507 \quad .299 \quad .332$

Fulfilling the needs of spouse

$.501 \quad .271 \quad .346$

Providing food and drinks to spouse

$.497 \quad .177 \quad .155$

Carrying out social activities with spouse (attending gatherings, dinner invitations)

$\begin{array}{lll}.493 \quad .307 & .298 \quad .307\end{array}$

Not inflicting injury to spouse

$\begin{array}{lll}.372 & -.033 & .221\end{array}$

Caressing spouse

$.271 \quad .757 \quad .161$

Hugging spouse

$.302 \quad .752 \quad .144$

Kissing spouse

Holding spouse's hands

$.221 \quad .751 \quad .136$

$.254 \quad .712 \quad .075$

Leading spouse by the hands

$\begin{array}{lll}.233 & .712 \quad .057\end{array}$

Holding spouse's waist

$\begin{array}{lll}.122 & .707 \quad .017\end{array}$

Uttering loving words to spouse

$\begin{array}{lll}.329 & .653 & .154\end{array}$

Giving spouse a massage

$.181 \quad .648 \quad .166$

Looking deeply into spouse's eyes

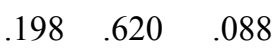

Praising spouse

$.477 \quad .563 \quad .177$

Smiling at spouse

$\begin{array}{lll}.382 & .555 \quad .049\end{array}$

Walking by spouse's side

$\begin{array}{lll}.386 & .555 \quad .041\end{array}$

Bathing with spouse

$.116 \quad .546 \quad .170$

Evoking memories of love from the past

$.259 \quad .540 \quad .296$

Creating romantic situations for spouse

$\begin{array}{lll}.329 & .535 \quad .355\end{array}$

Having sexual relations with spouse

$\begin{array}{lll}.236 & .486 & .213\end{array}$

Celebrating important dates involving spouse (such as wedding anniversaries, birthdays)

$.232 \quad .416 \quad .402$

Covering the aurat (parts of the body that should not be exposed according to Islamic law) for spouse

Upholding moral characters for spouse

$\begin{array}{lll}.375 & .095 \quad .667\end{array}$

Becoming a devout husband/wife for spouse

$.387 \quad 088 \quad .608$

Earning a living for spouse

$.057 \quad 097 \quad .559$

Ensuring spouse'safety

$\begin{array}{lll}.419 & .248 \quad .485\end{array}$

Buying gifts for spouse

$.199 \quad .401 \quad .439$

Providing spouse with financial assistance

$\begin{array}{lll}.269 & .134 \quad .431\end{array}$

Forgoing something (favourite activity, career/promotion) for the sake of spouse

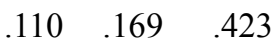

Table A2. Pattern/structure for coefficients: Oblimin rotation of EML 2 for 63 items

\begin{tabular}{lccc}
\hline Item (no.) & $\mathrm{C} 1$ & $\mathrm{C} 2$ & $\mathrm{C} 3$ \\
\hline Appreciating spouse & .814 & .505 & .387 \\
Respecting spouse & .809 & .510 & .338 \\
Cooperating with spouse & .807 & .491 & .377 \\
Discussing with spouse & .807 & .526 & .281
\end{tabular}


Being sincere with spouse

.799

Understanding spouse

Being worthy of spouse 's trust

Assisting spouse

Sharing stories with spouse

Making spouse happy

Communicating well with with spouse

Paying attention to spouse

Being considerate of spouse's feelings

Exchanging views with spouse

Sharing problems with spouse

Sharing problems with spouse

Concerned with the entire well-being of spouse

Listening to spouses's emotional outpourings

Giving words of encouragement to spouse

Encouraging spouse

Being truthful with spouse

Contacting spouse when apart (such as via text messages, emails, telephone calls)

Being with spouse in all circumstances

Dining with spouse

Joking with spouse

Speaking gently with spouse

Being faithful to spouse

Being courteous with spouse

Obtaining useful information for spouse

Carrying out recreational activities with spouse (such as watching television, going out)

Performing household duties with spouse (paying bills, doing the shopping, helping out with the children's homework, taking care of the children)

Fulfilling the needs of spouse

Carrying out social activities with spouse (attending gatherings, dinner invitations)

Ensuring and maintaining cleanliness of the thome for spouse

Accepting spouse for who he/she is

Trusting spouse

Ensuring spouse's safety

Providing food and drinks for spouse

Not inflicting injury to spouse

Hugging spouse

Caressing spouse

Kissing spouse

Holding spouse's hands

Leading spouse's hands

Uttering loving words to spouse
.798

$.401 \quad .427$

$\begin{array}{lll}.786 & .374 & .383\end{array}$

$\begin{array}{lll}.778 & .521 & .336\end{array}$

$\begin{array}{lll}.773 & .460 & .245\end{array}$

$\begin{array}{lll}.773 & .570 & .392\end{array}$

$\begin{array}{lll}.772 & .542 & .331\end{array}$

$\begin{array}{lll}.772 & .548 & .363\end{array}$

$\begin{array}{lll}.763 & .542 & .367\end{array}$

$\begin{array}{lll}.761 & .564 & .264\end{array}$

$\begin{array}{lll}.742 & .443 & .270\end{array}$

$\begin{array}{lll}.740 & .452 & .246\end{array}$

$\begin{array}{lll}.739 & .437 & .428\end{array}$

$\begin{array}{lll}.737 & .493 & .347\end{array}$

$\begin{array}{lll}.728 & .541 & .317\end{array}$

$\begin{array}{lll}.723 & .592 & .293\end{array}$

$\begin{array}{lll}.710 & .307 & .406\end{array}$

$\begin{array}{lll}.695 & .443 & .409\end{array}$

$\begin{array}{lll}.690 & .357 & .517\end{array}$

$\begin{array}{lll}.676 & .458 & .467\end{array}$

$\begin{array}{lll}.674 & .620 & .334\end{array}$

$\begin{array}{lll}.673 & .535 & .339\end{array}$

$\begin{array}{lll}.670 & .406 & .370\end{array}$

$\begin{array}{lll}.665 & .540 & .377\end{array}$

$\begin{array}{lll}.662 & .412 \quad .496\end{array}$

$\begin{array}{lll}.648 & .457 & .451\end{array}$

$\begin{array}{lll}.640 & .373 & .396\end{array}$

$\begin{array}{lll}.637 & .431 & .461\end{array}$

$\begin{array}{lll}.629 & .450 & .424\end{array}$

$\begin{array}{lll}.627 & .353 & .329\end{array}$

$\begin{array}{lll}.618 & .298 & .441\end{array}$

$\begin{array}{lll}.599 & .359 & .309\end{array}$

$\begin{array}{lll}.593 & .406 & .578\end{array}$

$\begin{array}{lll}.550 & .316 & .267\end{array}$

$\begin{array}{lll}.385 & .091 & .289\end{array}$

$\begin{array}{lll}.562 & .816 & .261\end{array}$

$\begin{array}{lll}.540 & .815 & .271\end{array}$

$\begin{array}{lll}.487 & .793 & .236\end{array}$

$\begin{array}{lll}.487 & .757 \quad .180\end{array}$

$\begin{array}{lll}.463 & .749 & .158\end{array}$

$\begin{array}{lll}.556 & .729 & .268\end{array}$ 
Holding spouse's waist

$\begin{array}{lll}.350 & .711 \quad .096\end{array}$

Giving spouse a massage

$\begin{array}{lll}.424 & .688 & .249\end{array}$

Praising spouse

$\begin{array}{lll}.666 & .683 \quad .314\end{array}$

Looking deeply into spouse's eyes

$\begin{array}{lll}.409 & .656 \quad .174\end{array}$

Creating romantic situations for spouse

$.572 \quad .642 \quad .455$

Similing to spouse

$\begin{array}{lll}.543 & .635 & .69\end{array}$

Walking by spouse's side

$.544 \quad 634 \quad .62$

Evoking memories of love from the past

$\begin{array}{lll}.495 & .621 \quad .384\end{array}$

Bathing with spouse

$\begin{array}{lll}.333 & .575 & .231\end{array}$

Having sexual relations with spouse

$\begin{array}{lll}.433 & .553 \quad .293\end{array}$

Celebrating important dates involving spouse (such as wedding anniversaries, birthdays)

$\begin{array}{lll}.459 & .510 & .472\end{array}$

Covering the aurat (parts of the body that should not be exposed according to Islamic law) for spouse

Upholding moral characters for spouse

$.432 \quad .189 \quad .751$

Becoming a devout husband/wife for spouse

$\begin{array}{lll}.554 & .272 \quad .735\end{array}$

Earning a living for spouse

$\begin{array}{lll}.545 & .260 \quad .679\end{array}$

Buying gifts for spouse

$\begin{array}{lll}.237 & .180 & .565\end{array}$

Providing spouse with financial assistance

$\begin{array}{lll}.434 & .491 \quad .500\end{array}$

Forgoing something (favourite activity, career/promotion) for the sake of spouse

$.406 \quad .252 \quad .486$

$.272 \quad .245 \quad .449$ 